\title{
Living up to your codes? Corporate codes of ethics and the cost of equity capital
}

\author{
Hong Kim Duong \\ School of Accountancy, Strome College of Business, Old Dominion University, \\ Norfolk, Virginia, USA \\ Marco Fasan \\ Department of Management, Ca' Foscari University of Venice, Venezia, Italy, and \\ Giorgio Gotti \\ School of Accountancy, UTRGV, Brownsville, Texas, USA
}

\begin{abstract}
Purpose - Previous literature provides mixed evidence about the effectiveness of a code of ethics in limiting managerial opportunism. While some studies find that code of ethics is merely window-dressing, others find that they do influence managers' behavior. The present study investigates whether the quality of a code of ethics decreases the cost of equity by limiting managerial opportunism.

Design/methodology/approach - In order to test the hypothesis, the authors perform an empirical analysis on a sample of US companies in the 2004-2012 period. The results are robust to a battery of robustness analyses that the authors performed in order to take care of endogeneity.

Findings - Empirical results indicate that a higher quality code of ethics is associated with a lower cost of equity. In other words, firms with a more comprehensive code of ethics and better-designed implementation procedures limit managerial opportunism and pay a lower cost of equity because they are perceived by investors to be less risky.

Research limitations/implications -

Practical implications -

Social implications -

Originality/value - The authors contribute to the literature in two ways. First, by looking at the market reaction to the code of ethics, thus capturing all its indirect possible benefits and second, by measuring not only the existence but also the quality of a code of ethics. Based on the results, policymakers may choose to further promote codes of ethics as an effective corporate governance mechanism.
\end{abstract}

Keywords Code of ethics, Business ethics, Managerial opportunism

Paper type Research paper

\section{Introduction}

Unethical behaviors by corporate executives - such as frauds, corruption, financial reports misstatement, improper use of company assets - make public opinion indignant (in the most striking cases forcing regulators to intervene), harm stakeholders, and destroy shareholders values. Frauds and corruption pose a tremendous threat to organizations in all parts of the world. Corporations are estimated to lose about five percent of their revenues to frauds each year [1]. In the US, the outrage over ethics by executives of public companies led to the passage of historic legislation in 2002, the Sarbanes-Oxley Act (SOX) (US Congress, 2002), which redefined, among other things, the role of the code of ethics in business. The legislation

\section{JEL Classification - G32, G34, M14}

(c) Hong Kim Duong, Marco Fasan and Giorgio Gotti. Published by Emerald Publishing Limited. This article is published under the Creative Commons Attribution (CC BY 4.0) licence. Anyone may reproduce, distribute, translate and create derivative works of this article (for both commercial and noncommercial purposes), subject to full attribution to the original publication and authors. The full terms of this licence may be seen at http://creativecommons.org/licences/by/4.0/legalcode
Code of ethics and cost of equity capital

Received 27 November 2020 Revised 22 March 2021 6 October 2021

Accepted 5 November 2021

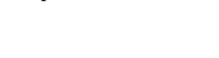


$\mathrm{MD}$

60,13

induced corporations to spend resources on creating a code of ethics that presumably is implemented to restrict unethical practices and create shareholder values (Orin, 2008).

Prior research documents mixed evidence about the effectiveness of a code of ethics. The most comprehensive and recent meta-analysis on the topic is by Kaptein and Schwartz (2008). The authors examine 79 empirical studies: $35 \%$ found that codes are effective; $16 \%$ found that the relationship is weak; $33 \%$ found that there is no significant relation, and $14 \%$ presented mixed results. The US's SOX does not mandate the content or implementation of a code of ethics: some firms merely adopt generic codes and make less-than-rigorous attempts to infuse the codes into the firm's ethical culture. Holder-Web and Cohen (2012) find that some codes of ethics are copied from industry associations. These codes are generic, vague, identical to one another, and so-called "off-the-shelf" codes. In contrast, some other firms adopt codes of ethics that not only satisfy the basic legal requirements but also reflect that careful thought and attention are consistently paid to the particular ethical conundrums of our times (Orin, 2008, p. 143).

More recently, Singh et al. (2018) pointed out that many studies have explored the contents of code of ethics, but few have examined what makes them effective. The relevance of a code of ethics is because it can enhance corporate reputation and brand image (Singh, 2011). Despite this, "there is a paucity of research examining the effectiveness of these documents and the organizational infrastructure that accompany them" (Singh, 2011, p. 385).

We aim to reconcile the mixed findings of the effectiveness of a code of ethics in prior studies by exploiting the variation in the quality of the code of ethics and by examining its impact on the cost of equity capital. Building on the model of Bicchieri (2006), we posit that a code of ethics will activate social norms that restrict opportunistic behaviors and reduce misconduct. Davidson and Stevens (2013) find that managers of a firm with a more comprehensive and better-implemented code of ethics gain investor confidence and receive more reinvestment for their firms. Ahluwalia et al. (2018) show that after the adoption of a code of ethics, managers become more diligent and engage more in financial scrutiny to cover past errors in their financial reports. This improvement in investor confidence and the reduction in misconduct may affect investors' risk assessment that translates into a lower cost of equity. In this study, we expect to find firms with a more comprehensive and betterimplemented code of ethics to have a lower cost of equity.

Using a novel dataset of the US S\&P 500 firms that capture the quality of a code of ethics for the period between 2004 and 2012, we examine the relationship between the code quality and the cost of equity. Consistent with our expectations, empirical results indicate that a higher quality code of ethics is associated with a lower cost of equity. In other words, firms with a more comprehensive code of ethics and better-designed implementation procedures pay a lower cost of equity because they are perceived by investors as being less risky. This finding is consistent with the prediction of Bicchieri (2006) model and the findings documented by Davidson and Stevens (2013) and Ahluwalia et al. (2018).

Like other code of ethics studies, one concern is that the endogeneity between the quality of a code of ethics and the cost of equity may cause spurious results. To address the issue, we employ multiple approaches: (1) change regression; (2) additional control variables to the baseline regression; (3) dynamic panel model using GMM technique to mitigate the issue of reverse causality; (4) Heckman two-stage regression to mitigate the issue of selection bias; and (5) difference-in-differences analysis. Overall, our main findings remain robust.

Our study contributes to the literature on the effectiveness of a code of ethics in several ways. We find that not only the adoption but also the implementation of a code of ethics creates benefits to companies. Due to data limitations, prior studies usually use the adoption or the existence of a code of ethics to measure corporate business ethics. Our measure of the quality of a code of ethics is more comprehensive and captures multiple attributes of a code of ethics: the adoption and comprehensiveness of a code; the compliance of a code via 
implementation systems; and the alignment between a firm's words and deeds of ethical practices related to human right and corruption issues. Our findings move the literature forward by showing that the implementation of a code of ethics and the alignment with ethical practices play a significant role in reducing the cost of equity. This missing key element - the implementation and the alignment with ethical practices - may be the reason for mixed findings in the extant literature.

Our study also contributes to practice in two main ways. First, companies may find our results useful in evaluating whether to invest resources in the implementation of a code of ethics. The decision about such an investment needs to be as rational as possible, and companies should weigh the benefits and costs of the implementation. Our work provides insights on the potential benefits, in terms of lower managerial opportunism.

The second way in which we contribute to practice is by highlighting that how a code of ethics is implemented does matter. Companies may consider our empirical result in choosing whether to adopt a more "tick the box" approach to code of ethics or whether to face a substantial investment that really impacts corporate governance and internal control systems. Our results show that the second approach is the most rational because it is the only one that can produce benefits.

The remainder of the paper is organized as follows. Section 2 summarizes the related literature on codes of ethics and the cost of equity. Section 3 discusses the theoretical underpinning of our analysis and develops hypotheses. Section 4 outlines the data sample and research design. Section 5 presents the empirical evidence, and Section 6 concludes the paper.

\section{Background}

\subsection{Codes of ethics}

Brenner (1992) defines an ethics program as values, policies, and activities driving employee behaviors. More specifically, he delineates two dimensions of an ethics program: explicit (such as codes of ethics, policy manuals, employee training materials ...) and implicit (such as corporate culture, valued behaviors, style of leadership ...). Given this broader context, codes of ethics are the key elements of an ethics program, around which other forms of institutionalization of ethics evolve (Remisova et al., 2019). We identify two different streams within the code of ethics literature, based on the conclusions about the effectiveness of a code of ethics.

The first stream (that we define as the "window dressing" view) finds that a code of ethics does not provide any benefit to companies implementing it. According to Warren (1993), a code of ethics provides superficial answers to the question of how to promote ethical behaviors. Dobel (2015) finds that codes of ethics make stakeholders more suspicious, cynical, and distrustful. Hess et al. (2005) argue that codes of ethics cost more than they yield. Lere and Gaumnitz (2003) employ insights from information economics to argue that a code of ethics is unlikely to have any impact on decision-making. Similarly, Long and Driscoll (2008) find that codes of ethics are used to gather legitimacy, but they are treated with insincerity by the organizations that adopt them.

Some studies find no evidence of a relationship between a code of ethics and legal violations (McKendall et al., 2002). More recently, Holder-Webb and Cohen (2012) in their article eloquently titled "The Cut and Paste Society: Isomorphism in Codes of Ethics", argue and find that a code of ethics is simply a response to the ethics-oriented rhetoric in the public arena and therefore it is unlikely to supply significant useful ethical guidance or constrain employee behaviors. Adelstein and Clegg (2016) criticize codes of ethics for being instrumental to risk management and for denying legitimacy to employee moral intuition.

The second stream of research (that we define as the "opportunism constraining" view) finds that a code of ethics is an effective tool to improve organizations' commitment and 
$\mathrm{MD}$

60,13

decision-making activity. Valentine and Barnett (2003) report that managers employed by companies with a code of ethics exhibit greater commitment. Similarly, Somers (2001) finds that accountants' commitment was higher in companies with a code of ethics than the commitment in those companies that did not have such a code.

Several studies find that codes of ethics shape and support decision-making (Brass et al., 1998; Schwartz, 2001). In particular, Pierce and Henry (1996), and Peterson (2002) find that the presence of a formal code has an impact on individual ethical decisions, and reduces illegality within corporations. McKinney et al. (2010), in their study of codes and ethical beliefs, show that businesspersons in organizations that have ethics codes are not likely to accept ethically questionable behaviors. Valentine et al. (2018) document that codes of ethics impact the ethical reasoning of employees. According to Ruiz et al. (2015), a formal code of ethics is the most common concrete organizational instrument to facilitate ethical reasoning and conduct.

The US public companies are not mandated to adopt a formal code of ethics until the passage of the SOX (US Congress, 2002) with Section 406 code of ethics. Effective on March 3, 2003, all public companies that fall under the SOX regulation of the SEC must meet the requirements of Section 406. Compliance with Section 406 means that the company must disclose whether it has adopted a code of ethics and if not the reasons, therefore. It is worth noting that Section 406 does not mandate the content or how the code must be implemented. The legislation induces corporations to spend resources on creating a code of ethics that presumably is implemented to restrict unethical practices and create shareholder values (Orin, 2008).

Several studies have examined the impact of a code of ethics on executive behaviors and financial reports after the passage of Section 406. Chen et al. (2018) find that a code of ethics deters earnings manipulation. Ahluwalia et al. (2018) investigate the impact of the adoption of a code of ethics and find that the adoption of a code of ethics improves the integrity of financial reporting by reducing restatements.

In summary, it is not clear whether a code of ethics is effective or creates benefits for companies. Prior studies only focus on causes and consequences of the existence, not on the content comprehensiveness or the implementation procedures of a code of ethics (the quality). These missing key elements of a code of ethics might be the reasons for the mixed findings in the extant literature. Little do we know whether and how well a code of ethics is implemented. Moreover, if a code of ethics is implemented, we do not know whether the implementation creates any benefits. In this study, we aim to fill in this gap in the literature.

\subsection{Cost of equity and its determinants}

Firms usually raise capital on the equity market by issuing stocks. The value of stocks on the market (stock price) reflects the present value of projected future cash flows for shareholders discounted for risk and time (Gebhardt et al., 2001). Higher risk implies a higher cost of equity and a lower stock price, ceteris paribus, as investors want to be compensated for the higher risk. The cost of equity is defined as the expected return on a firm's stock (Fama and Miller, 1972). In other words, it is the internal rate of return or the discount rate that the market applies to a firm's future cash flows to determine its current market value (El Ghoul et al., 2011).

Conceptually, the cost of equity can be measured as the discount rate that equates the expected future cash flows to the current stock price. The drivers of the cost of equity include the investors' perception of a firm's riskiness and future cash flows (Gebhardt et al., 2001; El Ghoul et al., 2011). A firm with a higher risk and/or lower future cash flows is expected to have a higher cost of equity.

Prior literature shows that a firm's cost of equity is impacted by its perceived risk, and managerial opportunism. Hong and Kacperzyk (2009) argue that firms operating in "sin" industries (e.g., gambling, tobacco, and guns industries) face substantial litigation risks and incur significant settlement costs. Equity investors perceive such firms as riskier and require 
a higher cost of capital. Kim and Sohn (2013) examine the impact of managerial opportunism reflected in earnings manipulation on the cost of capital and document that managerial opportunism exacerbates the information quality of earnings used by outside investors, and thus the equity investors demand a higher risk premium for these firms.

Previous studies document that equity investors consider the factors that mitigate managerial opportunism level of a firm and respond by requiring a lower risk premium. El Ghoul et al. (2011) examine the effect of corporate social responsibility on the cost of equity capital and find that firms with better CSR scores are perceived as being less risky and receive a lower cost of equity. Shen and Zhang (2020) examine the relation between CEO inside debt holdings on the cost of equity capital. Their findings suggest that CEOs inside debt holdings help to reduce the cost of equity capital because the debt holdings constrain the CEOs from excessive risk-taking and opportunistic behaviors.

\section{Hypothesis development}

Managerial opportunism is a central topic in the economics and management literature. According to Williamson's (1981) transaction cost theory, the determinants of transaction costs are frequency, specificity, uncertainty, limited rationality, and opportunistic behavior. Such opportunistic behavior is attributed to human nature. Agency theory (Jensen and Meckling, 1976) also leverages the idea of opportunism in predicting the behavior of managers (agents). Given information asymmetry and misalignment of interests, managers will act opportunistically at the expenses of shareholders (principals). Some scholars (see Pagano and Volpin, 2005; Cespa and Cestone, 2007; Benabou and Tirole, 2010) connected the idea of managerial opportunism and Corporate Social Responsibility (CSR) and proposed that CSR is an agency problem.

Based on these premises, a vast stream of literature developed on the corporate governance mechanisms that may reduce managerial opportunism. Virtually all the literature on corporate governance is at least partially aiming at reducing managerial opportunism through some mechanism (board of directors, independent directors, internal control systems, board diversity ....). In this broader context, codes of ethics represent one of the main corporate governance mechanisms used to reduce managerial opportunism.

While most of the studies about code of ethics do not make the theoretical mechanisms underlying their hypotheses explicit, we draw from the field of economics and we utilize Bicchieri's (2006) model of social norm activation to explain the reasons why codes of ethics may help reduce managerial opportunism. Bicchieri (2006) suggests that social norm activation creates relevant beliefs and expectations that impact behaviors. Davidson and Stevens (2013) assert that a code of ethics can affect this change in beliefs by activating social norms that help control opportunistic behaviors. More specifically, a code of ethics activates the social norms by (1) making relevant behavioral rules salient; (2) increasing the belief that a sufficiently large subset of the population conforms to the relevant behavioral rules made salient by the code, and (3) increasing the motivation to follow the relevant behavioral rules made salient by the code through the belief that such rules are valid or reasonable (Bicchieri, 2006).

Following the literature supporting the opportunism constraining view of a code of ethics and the models proposed by Bicchieri (2006), one would expect codes of ethics to shape employees' behavior by reducing their opportunism. As managerial opportunism is a source of risk, we would expect investors to consider, ceteris paribus, companies with a code of ethics to be less risky. Holder-Webb and Cohen (2012) argue that codes of ethics are mere rhetoric because of the way they are implemented by companies, not because of their intrinsic nature. Similarly, Anand et al. (2004) notice that Enron had a code of ethics, but this did not stop executives from behaving unethically and conclude that adopting a code of ethics is a positive development, but it is not sufficient. 
$\mathrm{MD}$

60,13

We build on the idea that the mere presence of a code of ethics is not enough to draw any definitive conclusions on its effectiveness and we take a step forward by studying the quality of the code of ethics. We define a code of ethics quality as reflecting the comprehensiveness of the code content and the comprehensiveness of the system for implementing it. Both elements are important determinants of a code's potential effectiveness (Chen et al., 2018). For instance, a code of ethics may have low comprehensiveness and only mention obeying laws and regulations. Conversely, it may have a high comprehensiveness, being more specific and providing more guidance on how to address problems related to giving and receiving bribes, gifts, facilitation payments, donations to political parties, and commitment to honesty, integrity, and fairness. A code may be implemented through a system with a low comprehensiveness, thus including only whistleblowing procedures, or it may rely on a system with high comprehensiveness and also providing employee training and compliance monitoring, including details of breaches and enforcements in reports, and undertaking a regular review of the code of ethics.

We posit that a code of ethics brings benefits only when it is developed to deter wrongdoing and promote ethical conduct and when such a code is infused into business culture through implementation. We refer these codes to high-quality codes of ethics. Based on the theoretical prediction of Bicchieri (2006), we expect to find a negative association between a high-quality code of ethics and the cost of equity.

We propose our hypothesis as follows:

H1. The higher the code of ethics quality, the lower the cost of equity.

\section{Research design}

\subsection{Data and sample}

Following prior research (Scholtens and Dam, 2007; Chen et al., 2018) we obtain the data on the corporate codes of ethics of US public firms included in the S\&P 500 index from the Ethical Investment Research Service (EIRIS) for the period 2004-2012. The sample is restricted to the S\&P 500 and the period due to the availability of corporate codes of ethics data. Our initial data sample from EIRIS has 3,520 firm-year observations. We then merge the EIRIS US sample with Compustat North America and the Center for Research in Security Prices (CRSP) and I/B/E/S databases to get financial and accounting data. The final main sample has 2,207 firm-year observations from 337 unique firms between the sample period 2004 and 2012.

\subsection{Regression variables}

4.2.1 Code of ethics quality. To specify our proxy for the quality of a code of ethics, we obtain the data on corporate codes of ethics from EIRIS, a non-profit, independent research organization. EIRIS has been conducting social, environmental, and ethical research on public firms since 1983. EIRIS gathers data annually through questionnaires and surveys across six different areas: the quality of a code of ethics, corporate governance, corporate social responsibility issues, environmental issues, human rights, and positive products and services. EIRIS database covers about 3,000 firms from 40 different countries. In the US, EIRIS covers all firms included in the S\&P 500 and this is the focus of our study. EIRIS code of ethics data has been used in prior research, i.e. Scholtens and Dam (2007) and Chen et al. (2018).

EIRIS organizes the various measures of the quality of a code of ethics into four categories: Systems (SYSTEM), Implementation (IMPLEMENT), Corruption (CORRUPT), and Human Right (HUMAN). SYSTEM is the measure of the comprehensiveness of a company's code of ethics, IMPLEMENT measures the extent to which a company has a 
system for implementing the code of ethics, CORRUPT is the company tolerance of unethical practices, $H U M A N$ measures the extent to which the company manages human right issues. For instance, SYSTEM is measured based on the answer to the question "Does the company have a code of ethics and, if so, how comprehensive is it?" The possible answers are coded as 0 if a company does not have a code of ethics, coded as 1 if a company has adopted a code of ethics but no further details available beyond this point, coded as 2 if a company has adopted a code of ethics and has only one specific ethics element out of the elements follows: obeys laws and regulations; prohibits giving and receiving bribes; restricts giving and receiving gifts; restricts facilitation payments; prohibits donations to political parties; and commitment to honesty, integrity, and fairness; coded as 3 if a company has adopted a code of ethics and the code has four or five specific ethics elements and coded as 4 if a company has adopted a code of ethics and the code has all specific ethics elements. Please refer to Appendix A for more detailed descriptions of the ethics component constructions.

To create an aggregate measure of corporate code of ethics, we use factor analysis to combine the four measures (SYSTEM, IMPLEMENT, CORRUPT, and HUMAN) of the quality of a code of ethics developed by EIRIS. Our factor analysis yields one factor with an Eigenvalue of 2.15. We name this factor ETHICS.

4.2.2 Cost of equity. Following Hail and Leuz (2006) and Dhaliwal et al. (2006), we estimate the ex ante cost of equity implied in the current stock prices and market expectations measured by financial analyst forecasts by using four different models: the Gebhardt et al. (2001), the Claus and Thomas (2001) model, the Ohlson and Juettner-Nauroth (2005) model, and the Easton (2004) model. We denote the cost of equity derived from the four above models $r_{-} G L S, r_{-} C T, r_{-} O J$, and $r_{-} E T$, respectively [2]. These four measures of the cost of equity have been used widely in accounting and finance literature [3]. However, there is no consensus as to the superiority of any particular model in estimating the cost of equity, and therefore limiting the empirical analysis to just one model measure may yield spurious results (Dhaliwal et al., 2006, p. 699). To reduce the spurious results associated with the use of one single model, we follow Dhaliwal et al. (2006) and Hail and Leuz (2006) and use the average of the four estimates of the cost of equity, $r \_A V G$, in our empirical tests.

4.2.3 Control variables. We follow prior studies (Hail and Leuz, 2006; Dhaliwal et al., 2006; El Ghoul et al., 2011; Shen and Zhang, 2020) to include controls shown to affect the cost of equity. The control variables include Beta $(B E T A)$, Size (SIZE), Book-to-market (BTM), Leverage $(L E V)$, Long-term growth rate $(L T G)$, Analyst forecast dispersion (DISP), Dividend payout $(D I V)$, Corporate Governance $(G O V)$, and Corporate social responsibility $(C S R)$.

4.2.4 Model specifications. To test our hypothesis, we use the following regression model:

$$
\begin{aligned}
r_{-} A V G_{i, t}= & \beta_{0}+\beta_{1} \text { ETHICS }+ \text { Controls }+\sum \text { YearIndicators } \\
& +\sum \text { IndustryIndicators }+\varepsilon_{i, t}
\end{aligned}
$$

where the subscripts $i$ and $t$ denote firm $i$ and year $t$, respectively. $r \_A V G$ is the average cost of equity, ETHICS is the measure of the quality of a code of ethics, and the control variables are specified above. Consistent with our hypothesis, we expect to find a significant and negative coefficient of $\beta_{1}$.

\section{Empirical results}

\subsection{Univariate analysis}

Table 1 reports descriptive statistics for ETHICS, the cost of equity variables $-r \_G L S, r \_C T$, $r \_O J, r \_E T$, and their average $r \_A V G$ - and control variables. The ETHICS scores exhibit large variation across firms over the sample period. The mean (median) of ETHICS in our 


\begin{tabular}{|c|c|c|c|c|c|c|c|c|c|}
\hline \multirow{6}{*}{$\begin{array}{l}\mathrm{MD} \\
60,13\end{array}$} & & $N$ & Mean & Min & $Q 1$ & Median & Q3 & Max & Standard deviation \\
\hline & $r_{-} A V G$ & 2,207 & $9.68 \%$ & $4.12 \%$ & $6.94 \%$ & $8.57 \%$ & $11.07 \%$ & $18.17 \%$ & $3.17 \%$ \\
\hline & ETHICS & 2,207 & 0.55 & 0.00 & 0.10 & 0.45 & 0.86 & 2.25 & 0.51 \\
\hline & BETA & 2,207 & 1.01 & -0.11 & 0.65 & 0.99 & 1.38 & 2.25 & 0.52 \\
\hline & SIZE & 2,207 & 16.13 & 14.68 & 15.43 & 16.01 & 16.72 & 18.43 & 0.87 \\
\hline & $B T M$ & 2,207 & 0.94 & 0.27 & 0.53 & 0.78 & 1.22 & 2.80 & 0.54 \\
\hline \multirow[t]{16}{*}{8} & $L E V$ & 2,207 & 0.20 & 0.00 & 0.10 & 0.20 & 0.29 & 0.50 & 0.13 \\
\hline & $L T G$ & 2,207 & $12.59 \%$ & $5.00 \%$ & $9.96 \%$ & $12.29 \%$ & $15.00 \%$ & $23.01 \%$ & $3.77 \%$ \\
\hline & $D I S P$ & 2,207 & 0.11 & 0.01 & 0.03 & 0.06 & 0.13 & 0.56 & 0.11 \\
\hline & GOV & 2,207 & 2.23 & 0.00 & 2.00 & 2.00 & 3.00 & 3.00 & 0.53 \\
\hline & CSR & 2,207 & 2.22 & 0.00 & 0.00 & 2.00 & 4.70 & 9.20 & 2.99 \\
\hline & $D I V$ & 2,207 & 0.20 & 0.00 & 0.00 & 0.17 & 0.33 & 0.77 & 0.20 \\
\hline & INST & 2,207 & 0.82 & 0.00 & 1.00 & 1.00 & 1.00 & 1.00 & 0.38 \\
\hline & ANACOV & $\begin{array}{l}2,207 \\
2,207\end{array}$ & 17.33 & 1.00 & 12.00 & 17.00 & 22.00 & 53.00 & 7.35 \\
\hline & SYSTEM & 2,207 & 3.40 & 0.00 & 3.00 & 4.00 & 4.00 & 4.00 & 0.86 \\
\hline & IMPLEMENT & 2,207 & 2.63 & 0.00 & 2.00 & 3.00 & 3.00 & 4.00 & 0.94 \\
\hline & CORRUPT & 2,207 & 1.34 & 0.00 & 0.00 & 2.00 & 2.00 & 3.00 & 0.91 \\
\hline & HUMAN & $\begin{array}{l}2,207 \\
2,207\end{array}$ & 0.41 & 0.00 & 0.00 & 0.00 & 1.00 & 3.00 & 0.70 \\
\hline & $r_{-} G L S$ & 2,207 & $7.54 \%$ & $3.62 \%$ & $6.98 \%$ & $7.31 \%$ & $8.81 \%$ & $12.64 \%$ & $2.04 \%$ \\
\hline & $r C T$ & 2,207 & $10.06 \%$ & $1.00 \%$ & $1.00 \%$ & $10.95 \%$ & $14.65 \%$ & $25.00 \%$ & $6.67 \%$ \\
\hline & $r O I$ & 2,207 & $6.47 \%$ & $0.18 \%$ & $1.00 \%$ & $1.49 \%$ & $13.28 \%$ & $24.84 \%$ & $7.41 \%$ \\
\hline & $r_{-} E T$ & 2,207 & $11.11 \%$ & $4.48 \%$ & $7.83 \%$ & $9.41 \%$ & $12.19 \%$ & $25.00 \%$ & $5.39 \%$ \\
\hline
\end{tabular}

Table 1.

Descriptive statistics

Note(s): This table presents the mean, minimum, first quartile, median, third quartile, maximum, and standard deviation of the regression variables for the main sample for the period between 2004 and 2012. A more detailed description of the variables is in Appendix A

sample is $0.55(0.45)$ with a standard deviation of 0.51 . The average cost of equity across four models is $9.68 \%$. The Easton (2004) model provides the highest estimate $(11.11 \%)$ while the Ohlson and Juettner-Nauroth (2005) yields the lowest estimate $(6.47 \%)$ for the cost of equity. The means of the cost of equity generated from the Gebhardt et al. (2001) model and from the Claus and Thomas (2001) are 7.54\% and $10.06 \%$, respectively. These estimates are in line with the results reported in Dhaliwal et al. (2006) and Hail and Leuz (2006).

Table 2 provides Pearson pairwise correlation coefficients of our main regression variables. The cost of equity variable $-r \_A V G$ - is significantly and negatively correlated with the quality of a code of ethics variable $-E T H I C S$. The correlation coefficient is -0.06 with a $p$-value of less than one percent. This result provides preliminary support to our first hypothesis.

Table 3 reports our univariate results of the test of our first hypothesis. We compare the means (panel A, Table 3) and the medians (panel B, Table 3) of each of the four costs of equity estimates $\left(r_{-} G L S, r_{-} C T, r_{-} O J, r_{-} E T\right)$ and their average $\left(r_{-} A V G\right)$ of the firms in the upper quartile with those of the firms in the lower quartile distribution of ETHICS. The mean (median) of the average cost of equity of firms in the upper quartile of ETHICS distribution is $9.40 \%(8.08 \%)$, while it is $9.84 \%(8.61 \%)$ for firms in the lower quartile. These results suggest that the mean (median) of the cost of equity for firms in the upper quartile is 44 (53) basis points lower than that for firms in the lower quartile of ETHICS score distribution. These differences are significant at the $5 \%$ level for the mean values and the $1 \%$ for median values. We find consistent results when examining the differences in mean and median values using each of the four estimates of the cost of equity. Overall, the univariate results suggest that consistent with the prediction of our first hypothesis, firms with a higher quality code of ethics have a significantly lower cost of equity. 


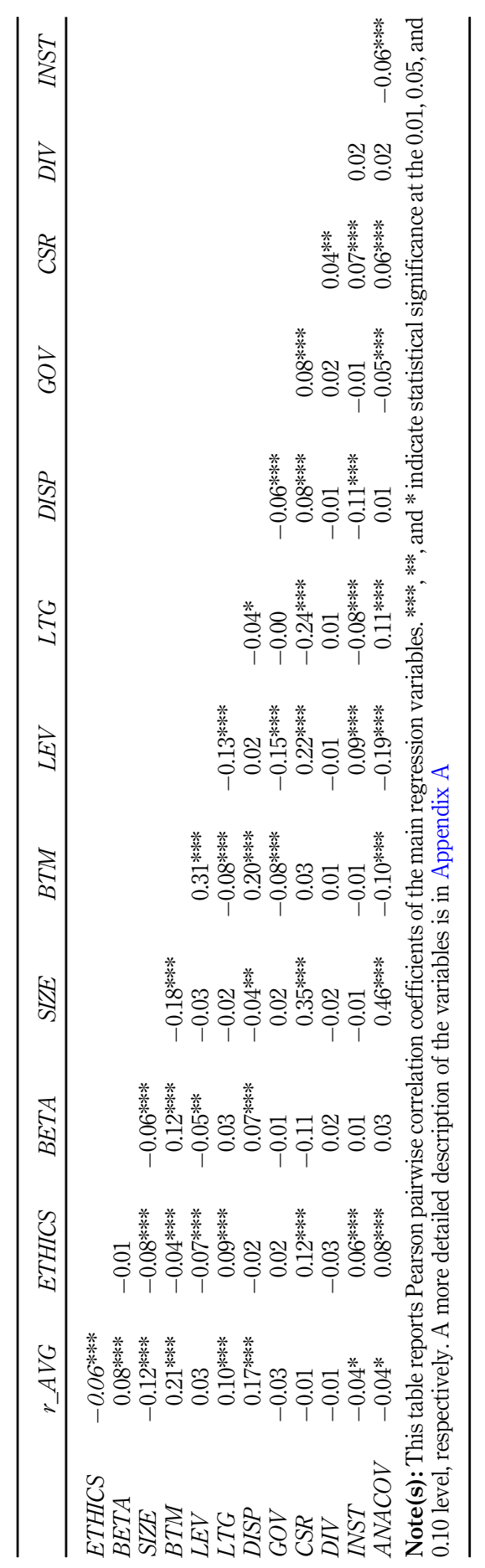

Code of ethics and cost of equity capital

9

Table 2. Correlation coefficients 


\begin{tabular}{|c|c|c|c|c|c|c|c|c|}
\hline \multirow{4}{*}{$\begin{array}{l}\mathrm{MD} \\
60,13\end{array}$} & & & \multirow[b]{2}{*}{$N$} & & & & & \\
\hline & & & & $r \_A V G$ & $r_{-} G L S$ & $r_{-} C T$ & $r_{-} O J$ & $r_{-} E T$ \\
\hline & $\begin{array}{l}\text { Panel A: Means } \\
\text { ETHICS in the } \\
\text { upper quartile }\end{array}$ & (1) & 548 & $9.40 \%$ & $7.48 \%$ & $9.84 \%$ & $7.57 \%$ & $11.96 \%$ \\
\hline & $\begin{array}{l}\text { ETHICS in the } \\
\text { lower quartile }\end{array}$ & (2) & 861 & $9.84 \%$ & $8.07 \%$ & $10.59 \%$ & $8.46 \%$ & $12.99 \%$ \\
\hline \multirow[t]{5}{*}{10} & Difference & $(1)-(2)$ & & $-0.44 \% * *$ & $-0.59 \%$ **** & $-0.75 \%$ *** & $-0.89 \% *$ & $-1.03 \% * *$ \\
\hline & $\begin{array}{l}\text { One sided } \\
p \text {-value }\end{array}$ & & & $\begin{array}{r}-1.04 \\
(0.05)\end{array}$ & $\begin{array}{l}-3.38 \\
(<0.01)\end{array}$ & $(<0.01)$ & $\begin{array}{c}-1.39 \\
(0.08)\end{array}$ & $\begin{array}{r}-1.10 \\
(0.04)\end{array}$ \\
\hline & $\begin{array}{l}\text { Panel B: Medians } \\
\text { ETHICS in the } \\
\text { upper quartile }\end{array}$ & (1) & 548 & $8.08 \%$ & $7.02 \%$ & $10.82 \%$ & $1.00 \%$ & $8.78 \%$ \\
\hline & $\begin{array}{l}\text { ETHICS in the } \\
\text { lower quartile }\end{array}$ & (2) & 861 & $8.61 \%$ & $7.76 \%$ & $11.16 \%$ & $2.08 \%$ & $9.74 \%$ \\
\hline & $\begin{array}{l}\text { Difference } \\
Z \text {-Statistic } \\
\text { One sided } \\
p \text {-value }\end{array}$ & (1)-(2) & & $\begin{array}{l}-0.53 \% * * * \\
-2.27 \\
(0.01)\end{array}$ & $\begin{array}{l}-0.74 \% * * \\
-4.46 \\
(0.04)\end{array}$ & $\begin{array}{l}-0.34 \% * * \\
1.33 \\
(0.05)\end{array}$ & $\begin{array}{l}-1.08 \% * * * \\
-2.38 \\
(0.01)\end{array}$ & $\begin{array}{l}-0.96 \% \text { **** } \\
-4.46 \\
(<0.01)\end{array}$ \\
\hline
\end{tabular}

Table 3.

Firms with high and low quality of code of ethics

Note(s): This table presents mean (panel A) and median (panel B) comparison tests for four individual and average cost of capital estimates across subsamples of upper and lower quartiles of ETHICS. The total sample includes 548 firm-year observations in the upper quartile subsample and 861 firm-year observations in the lower quartile subsample for the period between 2004 and 2012. ***, **, and * indicate statistical significance at the $0.01,0.05$, and 0.10 level, respectively. A more detailed description of the variables is in Appendix A

\subsection{Multivariate regression analysis}

In our multivariate tests, we regress the cost of equity variable $-r \_A V G$, on ETHICS and other control variables using pooled cross-sectional time-series regressions with robust standard errors clustered by firms and by years and controlling for industry and firm fixed effects. Table 4 reports the multivariate regression results. Consistent with our univariate results reported in Table 3, the multivariate regression results show a significant impact of ETHICS on the cost of equity. In Model 1, we examine the impact of ETHICS on the cost of equity while controlling for industry and year fixed effects. The coefficient of ETHICS is negatively significant. The result indicates that firms with a higher quality code of ethics have a significantly lower cost of equity. This significant relation remains robust when we include a battery of control variables. Overall, our multivariate results provide strong support to our first hypothesis that a higher quality code of ethics is associated with a lower cost of equity. Economically, the estimated coefficient of ETHICS in Column 2 suggests that a one-standarddeviation increase in ETHICS leads to a 29-basis-point reduction in the cost of equity.

In Table 5, we extend our analysis to examine the association between the quality of a code of ethics and each of the four estimates of the cost of equity (Columns 1 to 4), then the association between the average cost of equity and each of the measures of the quality of a code of ethics (Columns 5 to 8 ) and then, finally the association between the average cost of equity and all four measures of the quality of a code of ethics in Column 9.

We find that the coefficient of ETHICS is consistently negative and statistically significant when we use the individual measure of the cost of equity $\left(r \_G L S, r \_C T, r \_O J\right.$, and $\left.r \_E T\right)$. These results reinforce our earlier evidence that a higher quality code of ethics lowers the cost of equity. To provide more insights into the association between the quality of a code of ethics and the cost of equity, we re-examine and report the results of the association between each of the four measures of the quality of a code of ethics and the cost of equity in 
Dependent variable: $r_{-} A V G$

Predicted sign

\begin{tabular}{|c|c|c|c|}
\hline ETHICS & - & $-0.342^{* *}(-2.38)$ & $-0.288^{* * *}(-3.06)$ \\
\hline BETA & + & & $0.141(1.58)$ \\
\hline SIZE & - & & $-0.899 * * *(-3.62)$ \\
\hline$B T M$ & + & & $0.335^{*}(1.73)$ \\
\hline$L E V$ & + & & $0.581(0.53)$ \\
\hline$L T G$ & + & & $7.673 * * *(3.13)$ \\
\hline DISP & + & & $4.275 * * *(5.58)$ \\
\hline$D I V$ & - & & $-0.008^{* * * *}(-2.41)$ \\
\hline$G O V$ & - & & $0.009(0.59)$ \\
\hline CSR & - & & $0.322 *(1.71)$ \\
\hline INST & - & & $-0.023(-0.76)$ \\
\hline ANACOV & - & & $0.038 * *(2.01)$ \\
\hline ANABIAS & + & & $1.879(0.49)$ \\
\hline Year fixed effects & & Yes & Yes \\
\hline Industry fixed effects & & Yes & Yes \\
\hline$N$ & & 2,207 & 2,207 \\
\hline$R^{2}$ & & $3.56 \%$ & $13.68 \%$ \\
\hline
\end{tabular}

Note(s): This table presents the regression results of regressing the average cost of equity $\left(r \_A V G\right)$ on ETHICS and controls over the sample period between 2004 and 2012. Robust standard errors are clustered by firms. $t$-statistics are reported inside the parentheses. $* * * * *$, and $*$ indicate statistical significance at the 0.01 , 0.05 , and 0.10 level, respectively. A more detailed description of the variables is in Appendix A
Code of ethics and cost of equity capital

Table 4.

Code of Ethics Quality and the Cost of Equity - Multivariate results

Columns 5 to 8 of Table 5 . We aim to determine whether certain measures of the quality of a code of ethics are more important than the others in affecting a firm's cost of equity. The regression results suggest that all four measures of the quality of a code of ethics are negatively associated with the cost of equity. CORRUPT and HUMAN coefficients are statistically significant while SYSTEM and IMPLEMENT coefficients are statistically insignificant. We then include all four components of the quality of a code of ethics as independent variables in Column 9. All four components of the quality of a code of ethics are loaded negatively and statistically significant. The results suggest that while being separated, SYSTEM and IMPLEMENT do not have a significant effect on lowering the cost of equity. Recall that the SYSTEM variable measures the existence of a code of ethics and the comprehensiveness of the code if the firm has a code of ethics, and that IMPLEMENT measures a firm's compliance and implementation procedures of their code of ethics. The results are in line with Vethouse and Kandogan (2007) because if a firm has a code of ethics but does not implement it, then the code would be "window dressing" and should not have any effect. The results in Model 9 of Table 5 suggest that firms with a more comprehensive code of ethics and a system for implementing a code, policies, and procedures to deter corruption and bribery and a system and policies to address human rights issues would experience a significant lower cost of equity.

Our empirical results provide strong support for our first hypothesis, and they are in line with the "opportunism constraint view" of the code of ethics, conditional on the implementation of the code. The theoretical model underlying our analysis (Bicchieri, 2006) connects the code of ethics to the cost of equity through lower managerial opportunism and financial misconduct.

\subsection{Endogeneity concern}

Similar to other related corporate code of ethics studies, one concern is the potential endogeneity problem (driven by omitted variables, reverse causality, and sample selection 
MD

60,13

12

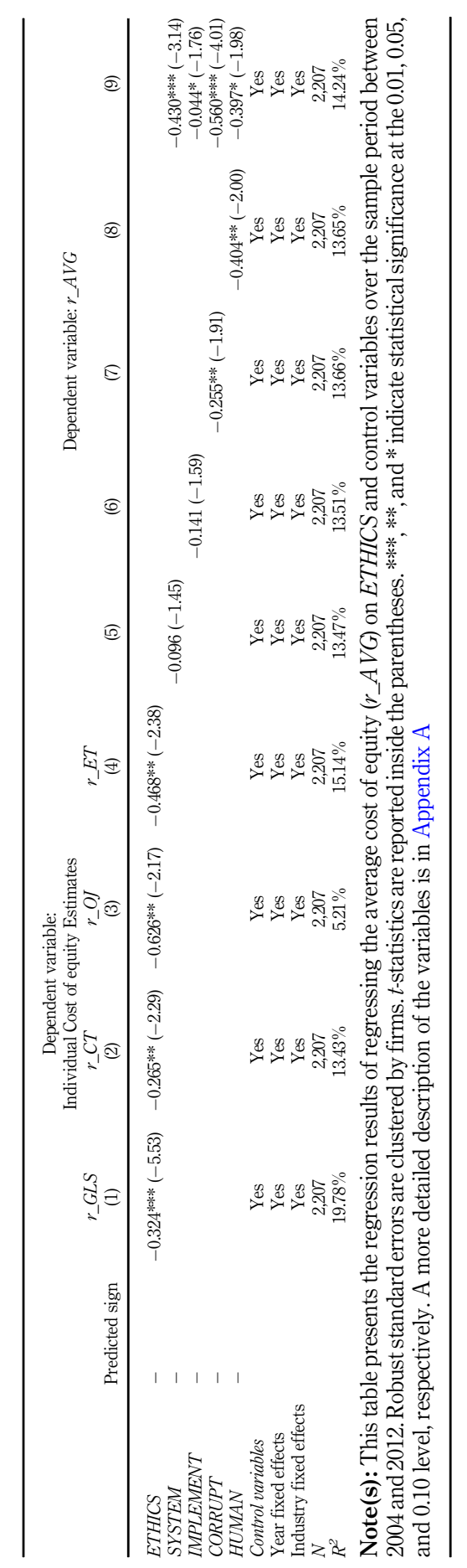

Table 5.

Individual measure of code of ethics quality and individual estimate of the cost of equity 
bias) which may cause spurious results about the relation between the quality of a code of ethics and the cost of equity. In this section, we employ five approaches to ensure the robustness of our analysis. The approaches include (1) change regression; (2) addition of earning quality and internal control as control variables to our baseline regression; (3) dynamic panel model estimated using GMM technique to mitigate the issue of reverse causality; (4) Heckman two-stage regression to mitigate the issue of selection bias and (5) difference-in-difference analysis.

First, the negative relation between the quality of a code of ethics and the cost of equity capital may be due to endogenous feedback from the cost of equity capital to a code of ethics. To deal with this concern, we estimate a model based on temporal changes in the cost of equity and changes in the quality of a code of ethics. The regression model is specified as follows:

$$
\Delta r_{-} A V G_{i, t}=\delta_{0}+\delta_{1} \Delta E T H I C S+\Delta \text { Controls }+\varphi_{i, t}
$$

where $\Delta$ indicates the change operator. The regression results of Model 2 are presented in Table 6 (Column 1). The coefficient of ETHICS is negative (-0.391) and significant at the 1 percent level ( $p$-value is 0.004$)$.

Second, to further mitigate the potential omitted variable bias and to improve the precision of our estimates, we add more control variables from prior research that are documented to have an impact on the cost of equity to our main regression model, such as earnings quality (Francis et al., 2008). The test results are reported in Table 6 (Columns 2 and 3) and they are consistent with our findings reported previously.

Beneish et al. (2008) and Ashbaugh-Skaife et al. (2009) provide evidence suggesting that the revelations of internal control deficiencies under SOX 404 affect a firm's cost of equity. To control for the impact of internal control deficiency, we include a dummy variable for internal control deficiency, ICD, in our robustness test and report the estimation results in Table 6 (Column 4). We use the same measure of internal control deficiency as in Doyle et al. (2007) and we obtain the data on $I C D$ from Sarah McVay's website. The estimation results are robust and support our prediction about the negative relation between the quality of a code of ethics and the cost of equity.

The third approach deals with the causality between code of ethics and the cost of equity and it is based on Klein (1998), which address the endogeneity concern of reverse causality (i.e. the quality of a code of ethics may be affected by the cost of equity in the previous period). We include the lagged cost of equity, $r_{-} A V G_{t-1}$, as an independent variable and estimate this dynamic panel model using the system GMM technique developed in Blundell and Bond (1998). The GMM estimation results are presented in Column 5 of Table 6 . We find that ETHICS continues to load negatively at the $5 \%$ confidence level, reinforcing our previous findings of a negative relation between the quality of a code of ethics (ETHICS) and the cost of equity capital.

Fourth, the selection bias may affect our results. To address the concern, we adopt the two-stage Heckman approach. In the first stage estimation, we include the proportion of firms that early adopted a code of ethics in an industry as an exogenous variable. The proportion of early-adopting firms can affect a firm's selection because of industry peer effects. Firms operating in an industry with more firms adopting a code of ethics are more likely to adopt a code of ethics and are more likely to implement the code. In the second stage, we include the inverse Mills ratio obtained from the first stage estimation as a control variable.

As specified in the Data and Sample in Section 4, our sample includes US public firms in the S\&P 500 index during the period between 2004 and 2012. Since the sample period is after the effective date of the disclosure requirement of Section 406 of the Sarbanes-Oxley 
$\mathrm{MD}$
60,13

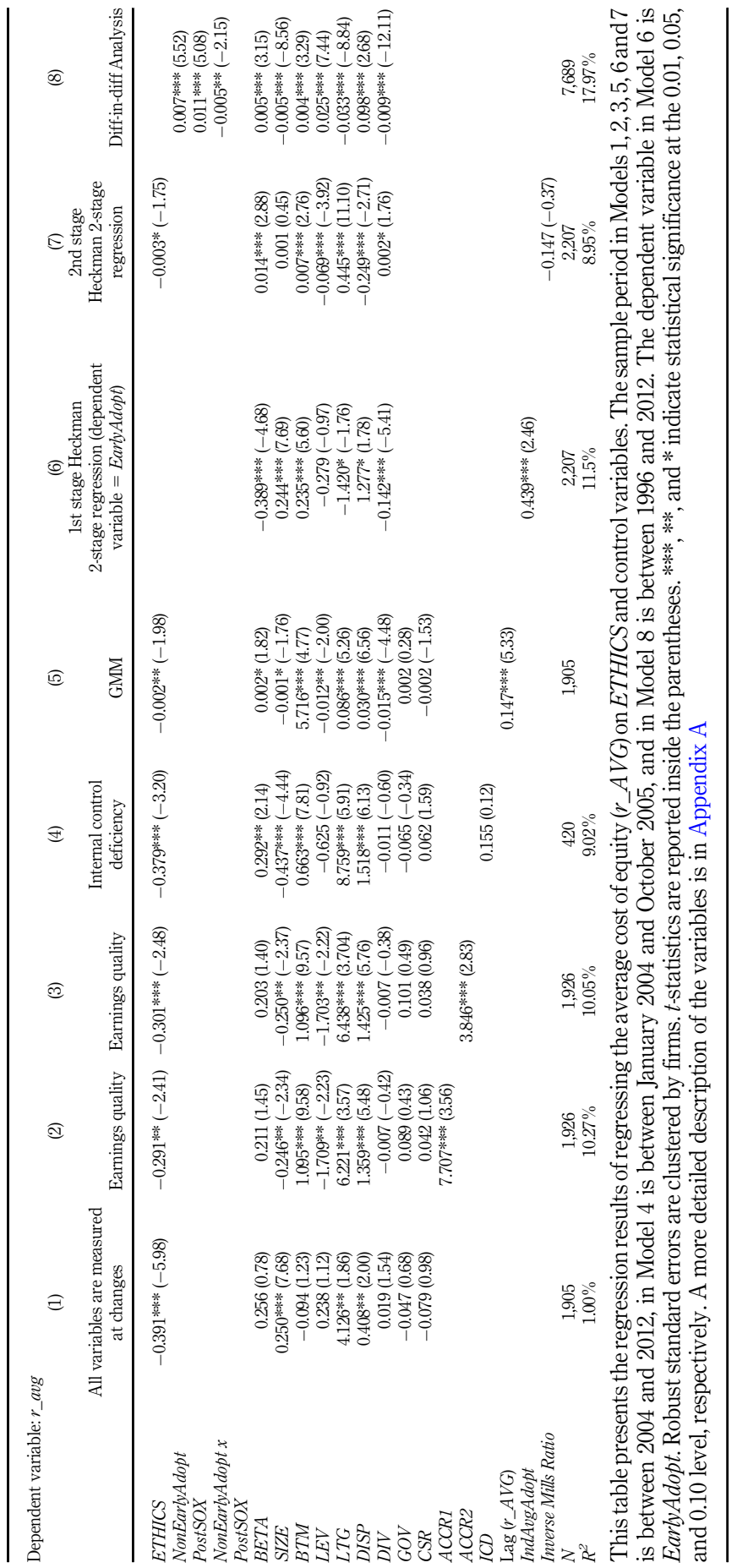

Table 6. 
Act (SOX), we would not assume that the firms not included in our sample do not adopt a code of ethics. Instead, we collect data of firms that voluntarily adopt a code of ethics before 2003, the disclosure requirement year of SOX. We call these firms "early adopters". To retrieve information on codes of ethics (also known as code of business conduct), we use a text search algorithm (web crawler) to search annual filings from the SEC website from 1996 to 2002. We start at the year 1996 because of the readability of SEC electronic filings. The keywords and phrases used for the search are: "code of ethics", "code of business conduct", "code of conduct", "code of business ethics", and "ethics". The web crawler retrieves the CIK from the filings and downloads the paragraph containing the key searching words or phrases into an excel file whenever it finds them. We then filter the search results by keeping only firms in the S\&P 500 index. The final sample has 2,205 firm-year observations, out of which 157 firms are code-ofethics early adopters. We then manually check these 157 early adopters to avoid a Type I error, where the null hypothesis of no line credit is rejected when in fact it is true. We do not find any errors among these 157 early adopters. We merge 157 early adopters to our main sample and create a dummy variable EarlyAdopt that takes the value of 1 if a firm is an early adopter and zero otherwise.

In the first stage of Heckman two-stage estimation, the dependent variable is EarlyAdopt, and an additional independent variable is the industry proportion of early adopters (IndAvgAdopt). Due to peer effects, firms operating in an industry with more early adopters tend to adopt a code of ethics. The first-stage probit model is specified as follows:

$$
\begin{aligned}
\text { EarlyAdopt }_{i, t}= & \gamma_{0}+\gamma_{1} \text { BETA }_{i, t}+\gamma_{2} \operatorname{SIZE}_{i, t}+\gamma_{3} B T M_{i, t}+\gamma_{4} L E V_{i, t}+\gamma_{5} L T G_{i, t} \\
& +\gamma_{6} D_{S} S P_{i, t}+\gamma_{7} D I V_{i, t}+\gamma_{8} I n d A d v A d o p t_{i, t}+v_{i, t}
\end{aligned}
$$

Details on the definitions and constructions of the variables are included in Appendix A. The estimation results of Model 3 are reported in Column 6 of Table 6 . The expected value of the dependent variable in Model 3 is included in the second stage estimation as the Inverse Mills Ratio and the second stage regression model is as follows:

$$
\begin{aligned}
r \_A V G_{i, t}= & \lambda_{0}+\lambda_{1} \text { ETHICS }+\lambda_{2} \text { InvMillsRatio }+ \text { Controls }+\sum \text { YearIndicators } \\
& +\sum \text { IndustryIndicators }+\varepsilon_{i, t}
\end{aligned}
$$

The estimation result of Model 4 is reported in Column 7 of Table 6. The Inverse Mills Ratio is statistically insignificant, indicating that there is no sample selection bias. The coefficient of ETHICS continues to be negatively significant and the results are consistent with our prior findings.

Finally, we use the passage of SOX Section 406 as a natural experiment and adopt the difference-in-differences approach to examine the impact of Section 406 compliance on the cost of equity. We use the early adopters as our baseline. If Section 406 compliance has any impact on the cost of equity, we would expect to find a negative coefficient on the interaction of the PostSOX dummy variable and NonEarlyAdopt variable. Our difference-in-difference regression model is specified as follows:

$$
\begin{aligned}
r A \text { VG }_{i, t}= & \theta_{0}+\theta_{1} \text { NonEarlyAdopt }_{i, t}+\theta_{2} \text { PostSOX }_{i, t}+\theta_{3} \text { NonEarlyAdopt } \times \text { PostSOX }_{i, t} \\
& + \text { Controls }+\varepsilon_{i, t}
\end{aligned}
$$

We use the dataset of a code of ethics adoption between 1996 and 2012 and use SOX as a natural experiment to conduct a difference-in-differences analysis. NonEarlyAdopt is a dummy variable that takes the value of 1 if a firm does not adopt a code of ethics before 2003 
$\mathrm{MD}$

60,13

and zero otherwise. PostSOX is a dummy variable that takes the value of 1 if the year is after 2003 and zero otherwise. Our variable of interest is the interaction between NonEarlyAdopt and PostSOX. If Section 406 mandatory compliance creates any impact on the cost of equity, then we expect to find the coefficient $\theta_{3}$ to be negatively significant. Consistent with our expectation, the coefficient $\theta_{3}$ is -0.005 and significant at less than $5 \%$ level (Column 8 , Table 6).

\section{Conclusions}

This paper examines whether the quality of a code of ethics affects a firm's cost of equity. While there is no previous evidence on this research question, previous literature offers arguments both supporting ("opportunism constraint view") and neglecting ("windowdressing view") the existence of a negative relation between the quality of a code of ethics and the cost of equity. Following Bicchieri's (2006) model of social norm activation and Davidson and Stevens (2013) assertion that a high-quality code of ethics can activate social norms that help to control opportunistic behaviors, we posit that firms with a higher quality code of ethics have a lower cost of equity. Using a sample of public firms included in the S\&P 500 index in the US, we find strong evidence supporting our hypothesis that a high-quality code of ethics significantly lowers the cost of equity. The findings are robust to a battery of robustness checks.

Overall, our findings suggest that not only the adoption but also the implementation of a code of ethics creates benefits to companies. Our findings move the literature forward by showing that the implementation of a code of ethics plays a significant role in reducing the cost of equity. This missing key element of implementation may be the reason for mixed findings in the extant literature. Section 406 of SOX only requires US firms to adopt a code of ethics but does not require the disclosure of the code content or the implementation procedures. Our findings highlight the importance of compliance and the alignment between words and deeds. Thus, SOX regulators may find our findings as a meaningful policy implication. Future research can extend our study by investigating other possible channels through which a high-quality code of ethics can lower the cost of equity.

Although our sample only includes the US S\&P 500 companies, the findings are meaningful not only for these company's shareholders but also for the stakeholders all over the world because more than $40 \%$ of the sales of the US S\&P 500 firms are to global customers. We call for future research to investigate the role of a code of ethics using other country samples to examine the role of institutional systems such as national culture, market development, and legal system on the effectiveness of a code of ethics.

Our results contribute to practice as companies may find our results useful in evaluating whether to invest resources in the implementation of a code of ethics. More specifically, we pointed out the benefits deriving from a code of ethics implementation. We also contribute to practice by highlighting that how a code of ethics is implemented does matter. More specifically, benefits in terms of lower managerial opportunism will arise only when companies actually (and not only formally) implement their code of ethics.

\section{Notes}

1. See the "Report to the nations" by the Association of Certified Fraud Examiners (ACFE). https:// www.acfe.com/report-to-the-nations/2020/, accessed November 3, 2020.

2. Please refer to Appendix B for detailed descriptions of these cost of equity measures.

3. Please refer to previous studies such as Dhaliwal et al. (2006), Hail and Leuz (2006), El Ghoul et al. (2011), Shen and Zhang (2020) in accounting and finance literature. 


\section{References}

Adelstein, J. and Clegg, S. (2016), "Code of ethics: a stratified vehicle for compliance", Journal of Business Ethics, Vol. 138 No. 1, pp. 53-66.

Ahluwalia, S., Ferrell, O.C., Ferrell, L. and Rittenburg, T.L. (2018), "Sarbanes-Oxley section 406 code of ethics for senior financial officers and firm behavior", Journal of Business Ethics, Vol. 151 No. 3, pp. 693-705.

Anand, V., Ashforth, B.E. and Joshi, M. (2004), "Business as usual: the acceptance and perpetuation of corruption in organizations", Academy of Management Perspectives, Vol. 18 No. 2, pp. 39-53.

Ashbaugh-Skaife, H., Collins, D.W. and Lafond, R. (2009), "The effect of SOX internal control deficiencies on firm risk and cost of equity", Journal of Accounting Research, Vol. 47 No. 1 , pp. 1-43.

Benabou, R. and Tirole, J. (2010), "Individual and corporate social responsibility", Economica, Vol. 77 No. 305 , pp. $1-19$.

Beneish, M.D., Billings, M.B. and Hodder, L.D. (2008), "Internal control weaknesses and information uncertainty”, The Accounting Review, Vol. 83 No. 3, pp. 665-703.

Bicchieri, C. (2006), The Grammar of Society: The Nature and Dynamics of Social Norms, Cambridge University Press, New York, NY.

Blundell, R. and Bond, S. (1998), "Initial conditions and moment restrictions in dynamic panel data models", Journal of Econometrics, Vol. 87 No. 1, pp. 115-143.

Brammer, S., Brooks, C. and Pavelin, S. (2006), "Corporate social performance and stock returns: UK evidence from disaggregate measures”, Financial Management, Vol. 35 No. 3, pp. 97-116.

Brass, D.J., Butterfield, K.D. and Skaggs, B.C. (1998), "Relationships and unethical behavior: a social network perspective", Academy of Management Review, Vol. 23 No. 1, pp. 14-31.

Brenner, S.N. (1992), "Ethics programs and their dimensions", Journal of Business Ethics, Vol. 11 Nos 5-6, pp. 391-399.

Cespa, G. and Cestone, G. (2007), "Corporate social responsibility and managerial entrenchment", Journal of Economics and Management Strategy, Vol. 16, pp. 741-777.

Chen, C., Gotti, G., Kang, T. and Wolfe, M.C. (2018), "Corporate codes of ethics, national culture, and earnings discretion: international evidence", Journal of Business Ethics, Vol. 151 No. 1, pp. 141-163.

Claus, J. and Thomas, J. (2001), "Equity premia as low as three percent? Evidence from analysts' earnings forecasts for domestic and international stock markets", The Journal of Finance, Vol. 56 No. 5, pp. 1629-1666.

Davidson, B.I. and Stevens, D.E. (2013), "Can a code of ethics improve manager behavior and investor confidence? An experimental study", The Accounting Review, Vol. 88 No. 1, pp. 51-74.

Dechow, P.M., Sloan, R.G. and Sweeney, A.P. (1995), "Detecting earnings management", The Accounting Review, Vol. 7 No. 2, pp. 193-225.

Dhaliwal, D., Heitzman, S. and Li, Z. (2006), “Taxes, leverage, and the cost of equity capital”, Journal of Accounting Research, Vol. 44 No. 4, pp. 691-723.

Dobel, J.P. (2015), “The realpolitik of ethics codes”, Ethics and Public Administration, New York, p. 158.

Doyle, J.T., Ge, W. and McVay, S. (2007), "Accruals quality and internal control over financial reporting", The Accounting Review, Vol. 82 No. 5, pp. 1141-1170.

Easton, P.D. (2004), "PE ratios, PEG ratios, and estimating the implied expected rate of return on equity capital", The Accounting Review, Vol. 79 No. 1, pp. 73-95.

El Ghoul, S., Guedhami, O., Kwok, C.C. and Mishra, D.R. (2011), "Does corporate social responsibility affect the cost of capital?”, Journal of Banking and Finance, Vol. 35 No. 9, pp. 2388-2406.

Fama, E.F. and French, K.R. (1997), "Industry costs of equity", Journal of Financial Economics, Vol. 43 No. 2, pp. 153-193.

Code of ethics and cost of equity capital 
$\mathrm{MD}$

60,13

Fama, E.F. and Miller, M.H. (1972), The Theory of Finance, Holt Rinehart and Winston, New York.

Francis, J., Nanda, D.J. and Olsson, P. (2008), "Voluntary disclosure, earnings quality, and cost of capital”, Journal of Accounting Research, Vol. 46 No. 1, pp. 53-99.

Gebhardt, W.R., Lee, C.M. and Swaminathan, B. (2001), "Toward an implied cost of capital”, Journal of Accounting Research, Vol. 39 No. 1, pp. 135-176.

Gode, D. and Mohanram, P. (2003), "Inferring the cost of capital using the Ohlson-Juettner model", Review of Accounting Studies, Vol. 8, pp. 399-431, doi: 10.1023/A:1027378728141.

Hail, L. and Leuz, C. (2006), "International differences in the cost of equity capital: do legal institutions and securities regulation matter?", Journal of Accounting Research, Vol. 44 No. 3, pp. 485-531.

Hess, D., McWhorter, R.S. and Fort, T.L. (2005), "The 2004 amendments to the federal sentencing guidelines and their implicit call for a symbiotic integration of business ethics", Fordham Journal of Corporate and Financial Law, New York, Vol. 11, p. 725.

Holder-Webb, L. and Cohen, J. (2012), "The cut and paste society: isomorphism in codes of ethics", Journal of Business Ethics, Vol. 107 No. 4, pp. 485-509.

Hong, H. and Kacperczyk, M. (2009), "The price of sin: the effects of social norms on markets", Journal of Financial Economics, Vol. 93 No. 1, pp. 15-36.

Jensen, M.C. and Meckling, W.H. (1976), "Theory of the firm: managerial behavior, agency costs and ownership structure", Journal of Financial Economics, Vol. 3 No. 4, pp. 305-360, doi: 10.1016/ 0304-405X(76)90026-X.

Kaptein, M. and Schwartz, M. (2008), "The effectiveness of business codes: a critical examination of existing studies and the development of an integrated research model”, Journal of Business Ethics, Vol. 77, pp. 111-127.

Kim, J.B. and Sohn, B.C. (2013), "Real earnings management and cost of capital", Journal of Accounting and Public Policy, Vol. 32 No. 6, pp. 518-543.

Klein, A. (1998), "Firm performance and board committee structure", The Journal of Law and Economics, Vol. 41 No. 1, pp. 275-304.

Kothari, S.P., Leone, A.J. and Wasley, C.E. (2005), "Performance matched discretionary accrual measures", Journal of Accounting and Economics, Vol. 39 No. 1, pp. 163-197.

Lere, J.C. and Gaumnitz, B.R. (2003), "The impact of codes of ethics on decision making: some insights from information economics", Journal of Business Ethics, Vol. 48 No. 4, pp. 365-379.

Long, B.S. and Driscoll, C. (2008), "Codes of ethics and the pursuit of organizational legitimacy: theoretical and empirical contributions", Journal of Business Ethics, Vol. 77 No. 2, pp. 173-189.

McKendall, M., DeMarr, B. and Jones-Rikkers, C. (2002), "Ethical compliance programs and corporate illegality: testing the assumptions of the corporate sentencing guidelines", Journal of Business Ethics, Vol. 37 No. 4, pp. 367-383.

McKinney, J.A., Emerson, T.L. and Neubert, M.J. (2010), "The effects of ethical codes on ethical perceptions of actions toward stakeholders", Journal of Business Ethics, Vol. 97 No. 4, pp. 505-516.

Ohlson, J.A. and Juettner-Nauroth, B.E. (2005), "Expected EPS and EPS growth as determinants of value", Review of Accounting Studies, Vol. 10 Nos 2-3, pp. 349-365.

Orin, R.M. (2008), "Ethical guidance and constraint under the Sarbanes-Oxley act of 2002", Journal of Accounting, Auditing and Finance, Vol. 23 No. 1, pp. 141-171.

Pagano, M. and Volpin, P.F. (2005), "Managers, workers, and corporate control”, Journal of Finance, Vol. 60 No. 2, pp. 841-868.

Peterson, D.K. (2002), "The relationship between unethical behavior and the dimensions of the ethical climate questionnaire", Journal of Business Ethics, Vol. 41 No. 4, pp. 313-326. 
Pierce, M.A. and Henry, J.W. (1996), "Computer ethics: the role of personal, informal, and formal codes", Journal of Business Ethics, Vol. 15 No. 4, pp. 425-437.

Ruiz, P., Martinez, R., Rodrigo, J. and Diaz, C. (2015), "Level of coherence among ethics program components and its impact on ethical intent", Journal of Business Ethics, Vol. 128 No. 4, pp. 725-742.

Scholtens, B. and Dam, L. (2007), "Cultural values and international differences in business ethics", Journal of Business Ethics, Vol. 75 No. 3, pp. 273-284.

Schwartz, M. (2001), "The nature of the relationship between corporate codes of ethics and behaviour", Journal of Business Ethics, Vol. 32 No. 3, pp. 247-262.

Shen, C.H. and Zhang, H. (2020), "What's good for you is good for me: the effect of CEO inside debt on the cost of equity", Journal of Corporate Finance, Vol. 64.

Singh, J.B. (2011), "Determinants of the effectiveness of corporate code of ethics: an empirical study", Journal of Business Ethics, Vol. 101, pp. 385-395.

Singh, J.B., Wood, G., Callaghan, M., Svensson, G. and Andersson, S. (2018), "Operationalizing business ethics in organizations. The views of executives in Australia, Canada and Sweden", European Business Review, Vol. 30 No. 4, pp. 494-510.

Somers, M.J. (2001), "Ethical codes of conduct and organizational context: a study of the relationship between codes of conduct, employee behavior and organizational values", Journal of Business Ethics, Vol. 30 No. 2, pp. 185-195.

U.S. Congress (2002), The Sarbanes-Oxley Act of 2002 (SOX). Public Law No. 107-204, Government Printing Office, Washington, DC.

Valentine, S. and Barnett, T. (2003), "Ethics code awareness, perceived ethical values, and organizational commitment", Journal of Personal Selling and Sales Management, Vol. 23 No. 4, pp. 359-367.

Valentine, S.R., Hanson, S.K. and Fleischman, G.M. (2018), "The presence of ethics codes and employees' internal locus of control, social aversion/malevolence, and ethical judgment of incivility: a study of smaller organizations", Journal of Business Ethics, Vol. 160 No. 3, pp. 657-674, doi: 10.1007/s10551-018-3880-8.

Vethouse, B. and Kandogan, Y. (2007), "Ethics in practice: what are managers really doing?", Journal of Business Ethics, Vol. 70, pp. 151-163.

Warren, R.C. (1993), “Codes of ethics: bricks without straw”, Business Ethics: A European Review, Vol. 2 No. 4, pp. 185-191.

Williamson, O.E. (1981), "The economics of organization: the transaction cost approach", The American Journal of Sociology, Vol. 87 No. 3, pp. 548-577.

\section{Further reading}

Donaldson, W.H. (2005), "Speech by SEC Chairman: remarks before the directors education institute", available at: https://www.sec.gov/news/speech/spch031605whd.htm.

Heckman, J.J. (1979), "Sample selection bias as a specification error", Econometrica, Vol. 47 No. 1, pp. 153-161.

Houston, J.F., Lev, B. and Tucker, J.W. (2010), "To guide or not to guide? Causes and consequences of stopping quarterly earnings guidance", Contemporary Accounting Research, Vol. 27 No. 1, pp. 143-185.

Kolk, A. and Van Tulder, R. (2004), "Ethics in international business: multinational approaches to child labor", Journal of World Business, Vol. 39 No. 1, pp. 49-60.

Kothari, S.P. (2001), "Capital markets research in accounting”, Journal of Accounting and Economics, Vol. 31 Nos 1-3, pp. 105-231.

Rich, A.J., Smith, C.S. and Mihalek, P.H. (1990), “Are corporate codes of conduct effective?", Management Accounting, Vol. 72 No. 3, pp. 34-35.
Code of ethics and cost of equity capital 
$\mathrm{MD}$

60,13

Appendix A

Variable definitions, constructions and data sources

\section{0}

\begin{tabular}{lll}
\hline Variable & Definition & Construction \\
\hline$r_{-} A V G$ & Average cost of equity & $r_{-} A V G=$ \\
& & $\left(r_{-} G L S+r_{-} C T+r_{-} O J+r_{-} E T\right) / 4$
\end{tabular}

Cost of equity derived from Gebhardt et al. (2001) model

$r+C T$

r_OJ

$r \_E T$

ETHICS

IMPLEMENT Compliance of a firm's code of ethics

Cost of equity derived from Claus and Thomas (2001) model

Cost of equity derived from Ohlson and Juettner-

Nauroth (2005) model

Cost of equity derived from Easton (2004) model

A code of ethics specifies an organization's primary values and ethical rules that are designed to promote right behaviors and deter wrong behaviors

SYSTEM Comprehensiveness of a firm's code of ethics
Details in Appendix B.1

Details in Appendix B.2

Details in Appendix B.3

Details in Appendix B.4

We conduct a factor analysis to aggregate the four measures of Ethics: Systems; Implementation; Corruption; and Human Right. The factor analysis provides one factor with Eigen value greater than one. We name this factor Ethics

The answer to the question: "Does the firm have a code of ethics and, if so, how comprehensive it is?" the possible answers are: no $($ coded $=0)$; limited $($ coded $=1)$; basic $($ coded $=2)$; intermediate ( $\operatorname{coded}=3$ ); and advanced $($ coded $=4)$

The answer to the question: "Does the firm have a system for implementing a code of ethics and, if so, how comprehensive it is?? the possible answers are: no (coded $=0)$; limited $($ coded $=1)$; basic $(\operatorname{coded}=2)$; intermediate (coded = 3); and advanced $($ coded $=4)$

\section{Data Source}

Authors'

calculations based

on $\mathrm{I} / \mathrm{B} / \mathrm{E} / \mathrm{S}$ and

compustat North

America

Authors'

calculations based

on $\mathrm{I} / \mathrm{B} / \mathrm{E} / \mathrm{S}$ and compustat North

America

Authors'

calculations based

on $\mathrm{I} / \mathrm{B} / \mathrm{E} / \mathrm{S}$ and compustat North

America

Authors'

calculations based

on $\mathrm{I} / \mathrm{B} / \mathrm{E} / \mathrm{S}$ and

compustat North

America

Authors'

calculations based

on $\mathrm{I} / \mathrm{B} / \mathrm{E} / \mathrm{S}$ and

compustat North

America

Authors'

calculations based

on ethical

investment research

service (EIRIS)

database

Ethical investment

research service

(EIRIS) database

Ethical investment research service (EIRIS) database 


\begin{tabular}{ll}
\hline Variable & Definition \\
\hline CORRUPT & $\begin{array}{l}\text { Deterrence of corruption } \\
\text { as a proxy for doing the } \\
\text { wrong things }\end{array}$
\end{tabular}

HUMAN Promotion of human right as a proxy for doing the right things

BETA Systematic risk

SIZE

Leverage

$L T G$

Long-term growth

DISP

$D I V$

GOV

Natural logarithm of a firm market value

Book-to-market

Analyst forecast dispersion

Dividend payment

Corporate governance

\section{Construction}

The answer to the question: "Does the company have policies and procedures on bribery and corruption?" the possible answers are: the firm has no policy disclosed (coded $=0)$; the firm has adopted a policy (coded $=1$ ); or the firm has a clear policy and procedures $($ coded $=2)$

The answers to the question: "What is the extent of policy and systems addressing human right issues?" the possible answers are: No evidence (coded as 0); limited (coded as 1); Intermediate (coded as 2); Advance or good (coded as 3)

The firm's rolling beta estimated by regressing 60 months excess stock returns ending in June of year $t$ on the corresponding monthly CRSP valueweighted index excess returns. Monthly excess returns are monthly returns minus the one-month treasury bill rate. We require a minimum of 12 months of observations in Beta estimation
Log (Fiscal year-end stock price $\mathrm{x}$ total common shares outstanding)

$\log \left(p r c c \_\right.$x $\left.c s h o\right)$

Total assets/(fiscal year-end stock price $\mathrm{x}$ total common shares outstanding) at/ (prcc $f \times$ x csho)

Total debt divided by total assets $(d l c+d l t t) / a t$

The average long-term growth forecast reported in June of year $t$

The standard deviation of one-yearahead analyst forecasts of earnings per share in June of year $t$

Total dividend payment scaled by net income. $d v t / n i$

The answers to the question: "Does the company: (1) separate the roles of chairman and chief executive; (2) have a board comprising of more than 33\% independent directors; (3) have an audit committee comprising a majority of independent directors; and (4) disclose executive and director remuneration?" the possible answers are: None (coded as 0 ); one (coded as 1); Some (coded as 2); All (coded as 3)

\section{Data Source}

Ethical investment research service (EIRIS) database

Authors' calculation based on CRSP data and market data from Ken French's website: http://mba. tuck.dartmouth.edu/ pages/Faculty/ken. French/data_library. html

Compustat North

America database

Compustat North

America database

Compustat North

America database

$\mathrm{I} / \mathrm{B} / \mathrm{E} / \mathrm{S}$ database

I/B/E/S database

Compustat North

America database Ethical investment research service (EIRIS) database

Ethical investment (EIRIS) database
Code of ethics and cost of equity capital

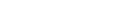

(continued) 
MD

60,13

\begin{tabular}{lll}
\hline Variable & Definition & Construction \\
\hline CSR & Corporate social & An aggregate measure of corporate \\
& responsibility & social responsibility based on three \\
& dimensions: (1) community \\
& performance (graded from 1 to 4); \\
& (2) environmental performance (graded \\
& from 1 to 5) and employee performance \\
& (graded from 1 to 3)
\end{tabular}

INST Institutional holding

Coded as 1 if a firm-year has at least one institutional holder reported in the form $13 \mathrm{~F}$ to the SEC

$\begin{array}{lll}\text { ANACOV } & \text { Analyst coverage } & \begin{array}{l}\text { Log }(1+\text { the number of analyst } \\ \text { estimates issued on a stock at the end of } \\ \text { the year) }\end{array} \\ \text { ANABIAS } & \text { Analyst forecast bias } & \begin{array}{l}\text { Difference between the mean value of } \\ \text { the 1-year-ahead consensus earnings } \\ \text { forecasts and actual earnings scaled by } \\ \text { stock price }\end{array} \\ \text { ACCR1 } & \text { Earnings quality } & \begin{array}{l}\text { Absolute value of abnormal accruals } \\ \text { estimated based on Dechow et al. (1995) } \\ \text { model }\end{array} \\ \text { ACCR2 } & \text { Earnings quality } & \begin{array}{l}\text { Absolute value of abnormal accruals } \\ \text { estimated based on Kothari } \text { et al. }(2005) \\ \text { model }\end{array}\end{array}$

ICD Internal control deficiency

A dummy variable that takes a value of 1 if a firm report internal control deficiency and zero otherwise

Data Source

Authors' calculation following the aggregation method specified in

Brammer and

Pavelin (2006) using ethical investment research service (EIRIS) database SEC website: https:// www.sec.gov/

divisions/ Investment/13flists. $\mathrm{htm}$

$\mathrm{I} / \mathrm{B} / \mathrm{E} / \mathrm{S}$ database

\section{I/B/E/S database}

Authors' calculations based on compustat North America database Authors' calculations based on compustat North America database The data contains material weakness disclosures from 2004 to 2005 , provided by Sarah McVay http:// faculty.washington. edu/smcvay/ICdata. html

$\begin{array}{lll}\text { EarlyAdopt } & \begin{array}{l}\text { Early adopted a code of } \\ \text { ethics in the period prior to } \\ 2003\end{array} & \begin{array}{l}\text { A dummy variable that takes a value of } \\ 1 \text { if a firm early adopts a code of ethics } \\ \text { before } 2003 \text { zero otherwise }\end{array}\end{array}$

IndAvgAdopt The industry proportion of firms early adopted a code

\section{Average of EarlyAdopt} of ethics prior to 2003

Inverse Mills The expected probability Ratio of early adoption of a code of ethics

Expected value of the dependent variable in Equation 4
Author's constructions based on the annual filings data available on SEC website Author's constructions based on the annual filings data available on SEC website Author's constructions based on the annual filings data available on SEC website and data from compustat North America 


\section{Appendix B}

\section{Cost of equity models}

\section{B.1. Gebhardt et al. (2001) model - r_GLS}

Gebhardt et al. (2001) model assume clean surplus accounting and allows share price to be expressed as forecasted returns on equity $(R O E)$ and book values $(B V)$. The forecast horizon is set to three years. After three years, forecasted $R O E$ is assumed to be equal to the median industry $R O E$ by the 12 th year and then remains constant. The industry classification is defined according to the Fama and French (1997) classification and the industry median $R O E$ is computed over the past ten years excluding loss firms. Dividend payout is assumed to be constant. The valuation equation is specified as follows:

$$
P_{t}=B V_{t}+\sum_{\tau+1}^{11} \frac{F R O E_{\tau+t}-k_{G L S}}{\left(1+k_{G L S}\right)^{\tau}} B_{t+\tau-1}+\frac{F R O E_{t+12}-k_{G L S}}{k_{G L S}\left(1+k_{G L S}\right)^{11}} B_{t+11}
$$

Where FROE is forecasted return on equity, $B V_{t+\tau}=B V_{t+\tau-1}\left(1-D P R_{t+\tau}\right)$ and $D P R$ is the expected dividend payout ratio and equals to the ratio between the actual dividend per share in year $t-1$ and actual earnings per share in year $t$-1. If earnings per share in year $t-1$ is negative, it will be replaced by the implied value of $6 \%$ return on assets which is the assumed long-term return on assets of the US).

\section{B.2. Claus and Thomas (2001) model $-r_{-} C T$}

Claus and Thomas (2001) model assumes clean surplus accounting and allows share price to be expressed as forecasted residual earnings and book values. The forecast horizon is set to five years. Beyond this set horizon, forecasted residual earnings grow at the inflation rate and dividend payout is assumed to be constant at $50 \%$. The valuation equation is specified as follow:

$$
P_{t}=B V_{t}+\sum_{\tau=1}^{5} \frac{a e_{t+\tau}}{\left(1+k_{C T}\right)^{\tau}}+\frac{a e_{t+5}(1+g)}{\left(k_{C T}-g\right)\left(1+k_{C T}\right)^{5}}
$$

Where $a e_{t+\tau}=$ ForecastedEPS $S_{t+\tau}-k_{C T} B V_{t+\tau-1}$ with ForecastedEPS is forecasted earnings per share. $B V$ is book value and $B V_{t+\tau}=B V_{t+\tau-1}+$ ForecastedEPS $S_{t+\tau}\left(1-D P R_{t+\tau}\right)$ with $D P R$ is the dividend payout ratio and equals to 0.5 , and $g=r_{f}$ - 0.03 with $r_{f}$ is 10 years-Treasury note yield rate obtained in June of each year. $k_{C T}$ is the cost of equity measured by using Claus and Thomas model.

\section{B.3. Ohlson and Juettner-Nauroth (2005) model - r_OJ}

Ohlson and Juettner-Nauroth (2005) model is a generalization of the Gordon constant growth model. This model allows share price to be expressed as the one-year-ahead earnings forecast, the near-term and perpetual growth forecasts. The forecast horizon is set to one year. After one year, the forecasted earnings grow at a near-term rate that equals to a perpetual rate. Following Gode and Mohanram's (2003) implementation of Ohlson and Juettner-Nauroth model, we compute the cost of equity as follows:

$$
k_{O J}+A+\sqrt{A^{2}+\frac{F E P S_{t+1}}{P_{t}}\left(g_{2}-(\gamma-1)\right)}
$$

Where $A=\frac{1}{2}\left((\gamma-1)+\frac{D P S_{t+1}}{P_{t 0}}\right), D P S_{t+1}=D P S_{O}, g_{2}=\frac{S T G+L T G}{2}, S T G=\frac{F E P S_{t+2}-F E P S_{t+1}}{F E P S_{t+1}}$, and $(\gamma-1)=r_{f}-0.03$. The near-term growth, $g_{2}$, is the average of the percentage difference between two-year-ahead and one-year-ahead earnings forecasts $(S T G)$, and the $\mathrm{I} / \mathrm{B} / \mathrm{E} / \mathrm{S}$ long-term growth forecast $(L T G)$. The perpetual growth rate is the expected inflation rate. Dividend per share is assumed to be constant. The model requires positive one-year-ahead and two-year-ahead earnings forecasts. 
$\mathrm{MD}$

60,13

B.4. Easton (2004) model - $r_{-} E T$

Easton (2004) model is a generalization of the price-earnings growth model and is based on the model of Ohlson and Juettner-Nauroth (2005). Easton (2004) model allows share price to be expressed as one-yearahead earnings forecasts. The forecast horizon is set to two years. After two years, forecasted abnormal earnings grow in perpetuity at a constant rate. The model requires positive one-year-ahead and twoyear-ahead earnings forecasts and positive change in earnings forecast. The model is specified as follow:

$$
P_{t}=\frac{F E P S_{t+2}+k_{E} D P S_{t+1}-F E P S_{t+1}}{k_{E}^{2}}
$$

Where $\mathrm{DPS}_{\mathrm{t}+1}=\mathrm{DPS}_{0}$.

B.5. Average cost of equity $-r_{-} A V G$

$$
r_{-} A V G=\left(r_{-} G L S+r_{-} C T+r_{-} O J+r_{-} E T\right) / 4
$$

\section{Corresponding author}

Marco Fasan can be contacted at: marco.fasan@unive.it

For instructions on how to order reprints of this article, please visit our website: www.emeraldgrouppublishing.com/licensing/reprints.htm Or contact us for further details: permissions@emeraldinsight.com 